\title{
Distribution of rare Cystoseira species along the Montenegro coast (South-Eastern Adriatic Sea)
}

\author{
VESNA MAČIĆ ${ }^{1}$ \\ BORIS ANTOLIĆ2 \\ ${ }^{1}$ Institute of marine biology, Dobrota b.b. \\ 85330 Kotor, Montenegro \\ E-mail:vmacic@ibmk.org \\ ${ }^{2}$ Institut of oceanography and fisheries \\ Šetalište I. Meštrovića 63; 21000 Split, Croatia
}

Keywords: Adriatic Sea, biodiversity, Cystoseira, regression

\begin{abstract}
Background and purpose: Multiple studies have shown that Cystoseira species are sensitive to anthropogenic impact, and a decrease in their populations was observed, especially close to urban areas. To better understand status of such endangered and protected species, we studied the distribution of six rare Cystoseira species along the Montenegro coast: C. compressa subsp. pustulata, C. crinita, C. crinitophylla, C. sauvageanana, C. sqarrosa and C. tamariscifolia.
\end{abstract}

Materials and methods: The study is based on field researches conducted through snorkelling and scuba diving along the Montenegrin coast during the period 1998-2009. In addition to the field work, we examined the published data for these species and the unpublished data from prof. Boris Antolic's field diary.

Results: Based on our 12-year-long investigations, we concluded that $C$. compressa subsp. pustulata, C. crinita, C. crinitophylla and C. sqarrosa are rare and endangered species along the Montenegro coast.

Conclusions: The published data for C. sauvageauana is likely mistaken due to incomplete and poorly conserved algal material, while regarding the reference for C. tamariscifolia should be checked if the collected sample was preserved. Furthermore, we noted that the habitat destruction and the proliferation of sea urchin populations have the most dramatic negative impact on the biocenosis formed by such rare and endangered Cystoseira species.

\section{INTRODUCTION}

The genus Cystoseira was identified in 1820 by the Swedish phycologist 1 Carl Adolph Agardh; it originally included 37 species, but most taxonomists currently accept approximately 50 Cystoseira species $(1,2)$. Most of them are registered in the Mediterranean Sea; few species were observed in the Atlantic (primarily Europe), and certain species were observed in the Pacific and Indian Oceans (3, 4, 5). Although certain Cystoseira species were described using samples from the Adriatic Sea and though an important and detailed work by Ercegović (6) refers to the east Adriatic coast, the Cystoseira vegetation in the South-East Adriatic Sea is not well understood, and data for such algae are few and incomplete. Furthermore, published data for the genus Cystoseira includes different numbers of taxa, even over a short period of time for both the Adriatic and Mediterranean Seas. For example, Ribera et al. (7) listed 47 taxa in the Mediterranean Sea and 29 in the Adriatic Sea, while Cormaci et al. (8) listed 29 taxa in the whole Mediterranean Sea. The differences are even more evident for
Received February 13, 2015.

Revised April 30, 2015.

Accepted July 17, 2015 
data from the west and east Adriatic Sea coasts, which were reported as having 18 and 30 taxa, respectively $(9,10)$. However, for the moment, the 35 Cystoseira taxa found in the Adriatic Sea likely represent an accurate indication of the Cystoseira diversity for this area $(9,10)$, while further taxonomy and molecular analisyes of this genera will give more light to the relationships between the species, varieties and forms $(10,11)$.

The genus Cystoseira is characteristic of the Mediterranean flora (2). These algae are often the dominant species on the rocky bottom and provide a suitable habitat for many additional species; thus, it is important to understand these algae's distribution and biocenosis. Moreover, a UNEP/RAC-SPA report (12) proposed protection for these species, and countries that are party to the Barcelona Convention are obliged to protect them. According to many published data, the Cystoseira species are sensitive to the anthropogenic impact, and a decrease in their populations was observed, especially in urban areas $(13,14,15,16,17)$. The studied species $C$. crinita, $C$. crinitophylla, C. sauvageauana and C. sqarrosa are endemic, while C. tamariscifolia and C. compressa subsp. pustulata are rare in the Mediterranean Sea. Therefore, the aim of this study was to present their distribution along the Montenegrin coast and provide useful information for future conservation.

\section{MATERIALS AND METHODS}

The study included 6 Cystoseira species and was based on field researches conducted through snorkelling and scuba diving along the Montenegrin coast (South-East Adriatic Sea) during the period 1998-2009.

The Montenegrin coast is located between Albania and Croatia and streches over about $90 \mathrm{~km}$ in straight line, but the entire length of the coast, including small islands is about $300 \mathrm{~km}$ (18). Along the coast of Montenegro 86 locations were surveyed by scuba diving and 18 by snorkeling. Sesonal field researches were conducted on 10 locations through 2005-2007, while other locations were surveyed randomly through different months of the year, and many of them several times in different periods of the same year, as well as several times during the period 19982009. Scuba diving was performed randomly down to the $40 \mathrm{~m}$ depth (if possible) and usually during $1 \mathrm{~h}$ of diving. All together 39 samples were collected for species $C$. compressa subsp. pustulata, Cystoseira crinita, C. crinitophylla and $C$. sqarrosa. For each of these species one sample were deposited (under labels: 2-2058, 2-2059, 2-2061 and 2-2063) in herbary collection of Faculty of biology, University Novi Sad (Serbia) -BUNS, (19). Three samples for each of these species were preserved in $4 \%$ formalin seawater, while others were preserved in $70 \%$ alchohol and deposited in the collection of the Institute of marine biology, Kotor (Montenegro). During this research samples of C. tamariscifolia and C. sauvageuana were not found.
In addition to the field work, we examined the published data for these species and the data from prof. Boris Antolićs field diary. The Antolic field diaries are unpublished data, held in the laboratory for benthos of the Institute of oceanography and fisheries in Split (Croatia). With all available data (taxonomy, data of collection, depth and bibliographic reference) a cartography and data base for six Cystoseira species was performed with Quantum GIS software Ver. 2.2.0. (20).

\section{RESULTS AND DISCUSSION}

\section{Cystoseira compressa subsp. pustulata (Ercegović) Verlaque}

In our research, $C$. compressa subsp. pustulata was only observed twice, at Perast $(6 \mathrm{~m})$ and at cape Kočište $(5 \mathrm{~m})$ (Fig. 1, 2A and Table 1). For locations on the open coast of Montenegro (cape Kočište), we should consider the negative impact from illegal date shell (Lithophaga lithophaga) collection and proliferating sea urchins populations that degrade habitats and reduce the Cystoseira and C. compressa subsp. pustulata populations $(17,21)$. Thus, it might be interesting to monitor barren areas and sea urchin populations because they are likely one of the dominant factors in Cystoseira biocenosis degradation.

Ercegović (6) reported this taxon mostly in the middle Adriatic Sea as C. abrotanifolia subsp. pustulata Ercegović. But we should have in mind that the taxonomy of Cystoseira compressa subsp. pustulata is quite confused. Giaccone and Bruni (1973) reduced this taxon to a heterotypic synonym of $C$. myriophylloides Sauvageau $(=C$. humilis Schousboe ex Kützing), a species described from Atlantic France (11, 23). According to Thibaut et al. (11) C. compressa subsp. pustulata axes are frequently compressed at the basis, the branches are more or less distichously inserted in one plane and the cryptostomata are large and prominent (whence the name 'pustulata'). On the basis of a same authors study of genuine Atlantic specimens of $C$. humilis from Canary Islands, Spain and Morocco there is a distinction between the two taxa. In C. humilis the axes are always cylindrical, the branches are never distichously inserted (thallus with pyramidal outline) and the cryptostomata are inconspicuous (branches smooth) (11). Because of all this, our samples were described as $C$. compressa subsp. pustulata. Furthermore, we urge to pay attention and check reports for $C$. humilis for the possible future analysies of $C$. compressa subsp. pustulata distribution in Adriatic Sea (10) and beyond.

\section{Cystoseira crinita Duby}

The distribution of $C$. crinita along the Montenegrin coast is shown in Fig. 1, 2B and Tab. 1 , with 6 locations from published data and 13 total observations. We only observed C. crinita on the open sea, primarily on the highly exposed coast, as it was also observed by Špan and 
Tab. 1. Details on rare Cystoseira species observations along the Montenegro coast

\begin{tabular}{|c|c|c|c|c|c|}
\hline Species & location & depth (m) & sampling date & source of data & location no. on the map \\
\hline \multirow{3}{*}{$\begin{array}{l}\text { C. compressa subsp. } \\
\text { pustulata }\end{array}$} & Perast & 6 & 23.08.2006. & this study & 5 \\
\hline & rt Kociste & 5 & 12.05 .2007 & this study & 16 \\
\hline & Platamuni & & $1984-1985$ & Lovric, Rac, 2006 & 20 \\
\hline \multirow{13}{*}{ C. crinita } & rt Kočište & 5 & 12. 05. 2007. & this study & 16 \\
\hline & Ponta Veslo & 4 & 03.09 .2006$. & this study & 15 \\
\hline & Kamenovo & 1,5 & 25.08 .2006 & this study & 21 \\
\hline & Ponta Veslo & 1 & 18. 06. 2006. & this study & 15 \\
\hline & rt Dobreč & 5 & 01. 09. 2006. & this study & 13 \\
\hline & rt Žukovac & 3 & 14. 08. 2007. & this study & 19 \\
\hline & rt Kočište & 5 & 25. 10. 2006. & this study & 16 \\
\hline & Platamuni & & $1984-1985$ & Lovric, Rac, 2006. & 20 \\
\hline & Bigova & & $1984-1985$ & Lovric, Rac, 2006. & 18 \\
\hline & Radimiri & & 1970 & Solazzi, 1971. & 2 \\
\hline & Prčanj & 5 & 1970 & Solazzi, 1971. & 1 \\
\hline & Ulcinj & 0 & 26. 06.1950. & Ercegović, 1952. & 24 \\
\hline & u. Trašte & & $1986-1987$ & Špan, Antolić, 1987. & 17 \\
\hline \multirow{11}{*}{ C. crinitophylla } & iza Perasta ponte & 2,5 & 24.08.1997. & this study & 7 \\
\hline & iza Orahovca & 3 & 09.07.1997. & this study & 4 \\
\hline & Krasici & 0.5 & 05.09.2006. & this study & 11 \\
\hline & rt Dobrec & & 01.09.2006. & this study & 13 \\
\hline & Perast & 3 & 23.08.2006. & this study & 6 \\
\hline & Kamenovo & & 25.08.2006. & this study & 21 \\
\hline & Orahovac & 3 & 23.08.2006. & this study & 3 \\
\hline & $\begin{array}{l}\text { o. Gospa od } \\
\text { Škrpjela }\end{array}$ & 1 & 1986 & Špan, Antolić, 1992 & 8 \\
\hline & Krašići & 0.7 & 1986 & Špan, Antolić, 1992 & 10 \\
\hline & Rt Kobila & $0,5-2,5$ & 19.08.1989. & Antolićs's field diary & 12 \\
\hline & Uvala Trašte (istok) & $0-3$ & 19.09.1986. & Antolić's field diary & 17 \\
\hline C. sauvageauana & Perast & $10-15$ & 1970 & Solazzi, 1971 & 6 \\
\hline \multirow{6}{*}{ C. squarrosa } & Posejdonov grad & 1,5 & 22.07.2008. & this study & 14 \\
\hline & Ponta Veslo & 1 & 10.05.2009. & this study & 15 \\
\hline & Platamuni & & $1984-1985$ & Lovric, Rac, 2006 & 20 \\
\hline & Bigova & & $1984-1985$ & Lovric, Rac, 2006 & 18 \\
\hline & rt Voluica & & $1979-1981$ & Span, Antolic, 1983 & 22 \\
\hline & rt Mendra & & $1979-1981$ & Span, Antolic, 1983 & 23 \\
\hline C. tamariscifolia & Solila & & $1984-1985$ & Lovric, Rac, 2006 & 9 \\
\hline
\end{tabular}

Antolić (24). However, this species was observed in this area at depths ranging from the one to $5 \mathrm{~m}$; thus, this alga likely prefers locations with moderate water movement, which has been reported for additional locations in the Mediterranean $(6,25,26,27)$. Overgrazing by sea urchins and habitat destruction by illegal date shell (Lithophaga lithophaga) collection has likely had the greatest negative impact on this alga $(17,21,28)$.

\section{Cystoseira crinitophylla Ercegovic}

C. crinitophylla populations along the Montenegrin coast are presented with two literature data, two data from Prof. Antolićs's field diary and our 7 observations (Fig. 1, Fig. 2C, Tab. 1). The first description of this species was done by Ercegović (6) on the base of samples from the Adriatic Sea and the most southern observation in the 


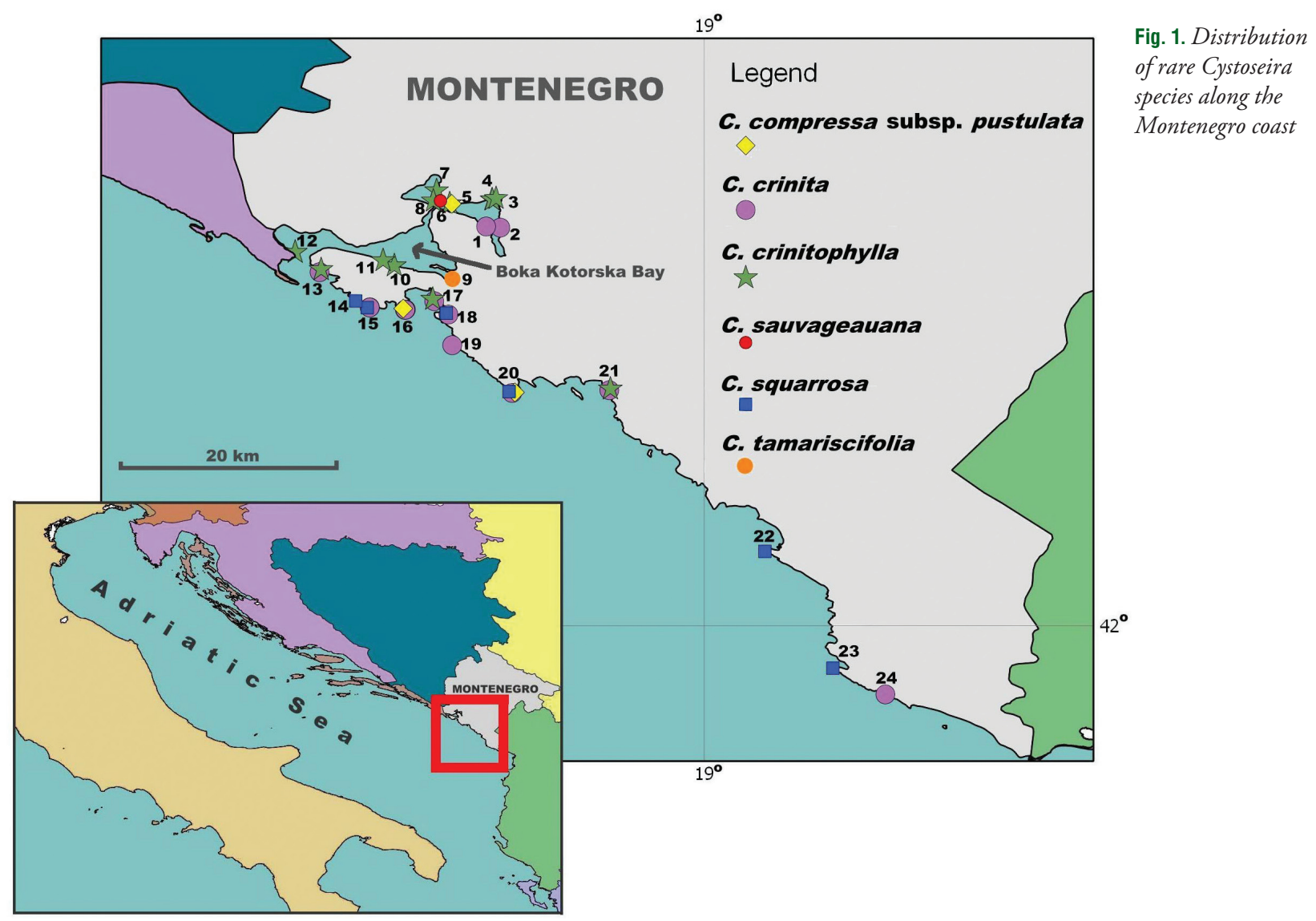

Adriatic Sea was in Boka Kotorska Bay (29). In our research, we found C. crinitophylla in the bay and at a more southern locations on capes Dobrec (entrance in the Bay of Boka Kotorska) and Kamenovo (close to Budva town). Finding from Antolićs field diary for the location "uvala Trašte” was not confirmed, while report for Krašići was confermed in 2004. Unfortunately, for location Krašići we observed also species disappearance due to new construction on the coast in 2006. Due to the limited data from earlier periods and intensive urbanisation in the Bay of Boka Kotorska, we can only assume that such habitat destruction yielded a negative anthropogenic impact on additional $C$. crinitophylla populations.

At each location in our field research, C. crinitophylla populations were observed as a small number of individuals, and compared with certain other Cystoseira species on the Montegrian coast, C. crinitophylla is rare.

The habitat for this species is a rocky coast from the surface to a depth of $10 \mathrm{~m}$, which explains why the potential threats to this alga include habitat destruction, overgrazing by sea urchins, pollution and competition with non-native species $(17,21,28,30,31)$.

\section{Cystoseira sauvageuana Hamel}

There is only one reference available for $C$. sauvageuana distribution along the Montenegro coast, at Perast, at a depth of 10-15 m (32). We did not observe this species during our research (Fig. 1, Tab. 1). Solazzi (32) reported the presence of $C$. selaginoides Val., which is a synonym for $C$. sauvageuana Hamel $(23,33,34)$. However, Solazzi emphasised that he analysed algal material of small dimensions that, in certain cases, were incomplete and not well preserved. Researches on C. sauvageuana morphology, reproductivity and fenology $(35,36)$ showed that its taxonomical characteristics are varying throughout the year, such as pseudotophules and spines at the apex; thus, for accurate analyses, specimens should be collected from the same location throughout the year. Moreover, this species has only been referenced in the Adriatic Sea by Solazzi (32) (and Ribera et al. (7) who cited Solazzi); we did not find any additional citations for this species in the Adriatic Sea. In the Catalogue of macrophytobenthos of Italy, Furnari et al. (9) did not report $C$. sauvageuana for the Adriatic Sea, but only for Sicily, Calabria, Campania and Puglia (close to Taranto). Gomez-Garreta (25) and Ribera et al. (7) observed that this species was more common in the west Mediterranean and it is typically observed in rocky bottom environments at a few meters of depth. Solazzi (32) reported this algae at a depth of 10-15 $\mathrm{m}$ in the Bay of Boka Kotorska, where the water transparency is typically low (37). Based on these details, we think that this citation could be a misreported data. We did not check for the existence of herbarium samples of the material analysed by Solazzi, but we think this material should be consulted in the nearby future. 
Fig. 2. Photos of rare Cystoseira species found along the Montenegro coast: A) C. compressa subsp. pustulata,

B) C. crinita,

C) C. crinitophylla and D) C. sqarrosa

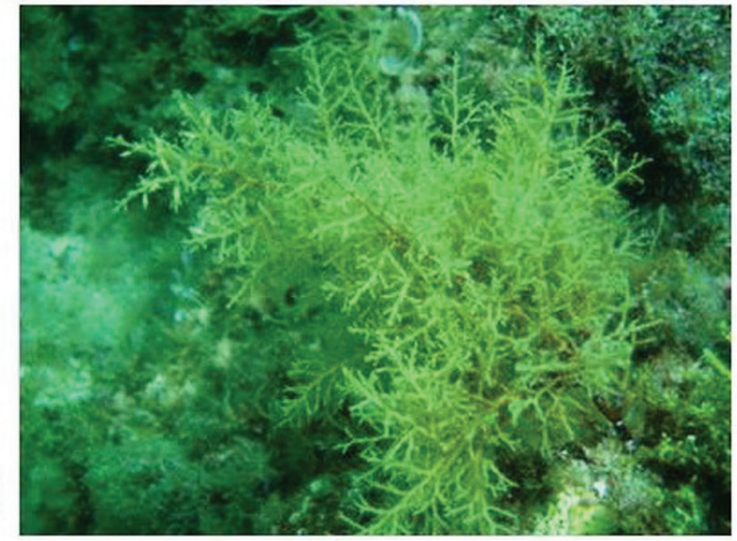

B)
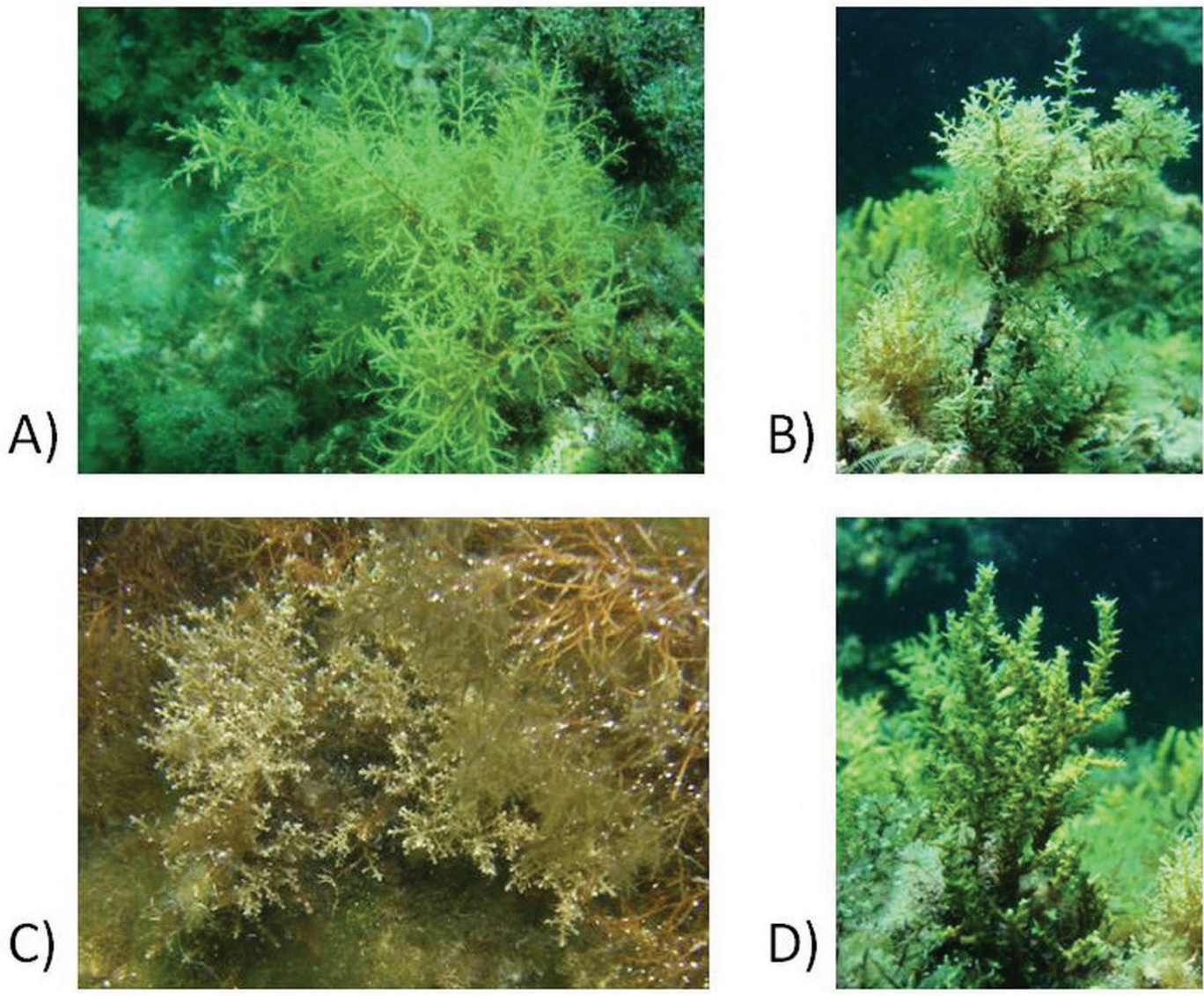

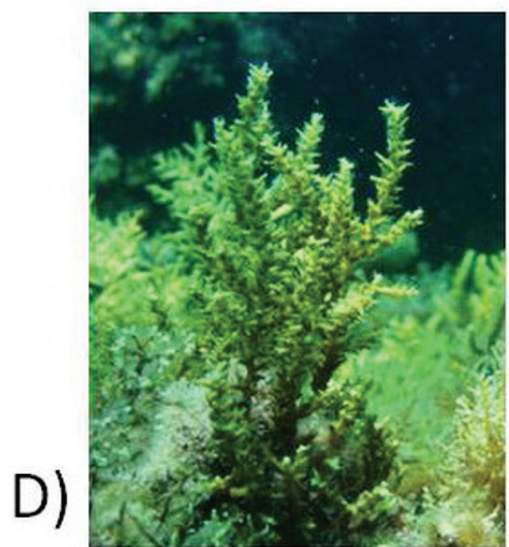

\section{Cystoseira squarrosa De Notaris}

C. squarrosa is a rare, endemic species in the Mediterranean Sea $(13,38,39)$ that Ercegovic (6) observed in the South-East Adriatic Sea. For the Montenegro coast, this alga was first reported by Span and Antolic (40) on capes Voluica and Mendra. We observed C. squarrosa at two locations: Posejdonov Grad and Ponta Veslo (Lustica Peninsula), both at a depth of $1 \mathrm{~m}$ (Fig. 1, 2D, Tab. 1). During our field work, we observed only small populations with a few individuals. Furthermore, locations reported by Lovric and Rac (43) were checked again in 2010. but findings of $C$. squarrosa were not confirmed, while locations $\mathrm{rt}$ Voluica and rt Mendra reported by Span and Antolic (40) were not controlled again durring this research.

The decline in population for this species has been reported in different Mediterranean locations (38, 41); it is likely also vulnerable in the Montenegrin coast. Locations with $C$. squarrosa herein and in published data are not in urbanised areas of the Montenegrin coast, except location Bigova (42). Thus, habitat destruction and pollution from waste water are not a current threat, but overgrazing by sea urchins is a serious threat $(17,21,28,30)$. Competition with alochtonous species could also be a threat for this alga, especially because dense populations of Caulerpa racemosa and Womersleyella setacea on location Ponta Veslo $(31,42)$.

\section{Cystoseira tamariscifolia (Hudson) Papenfuss}

For the Montenegrin coast and the Adriatic Sea, $C$. tamariscifolia is reported only in one location, the Boka Kotorska Bay, Solila (43) (Fig. 1, Tab.1). Some studies described this alga as being located in the west Mediterranean and Atlantic coasts of Europe and North Africa (9, 22, 25, 44). The literature indicates $(7,9,23,25,44,45)$ that this species is rare and vulnerable and that its populations are highly exposed to the negative anthropogenic impact, primarily through habitat destruction and pollution. Since we did not find C. tamariscifolia in our field work (19982009), and Lovric and Rac (43) collected their algal material in 1984-1985, the species may have disappeared. But, this species was not observed in any other Adriatic Sea location $(9,10)$ so, it would be useful to verify the determination of the algal material collected by Lovric and Rac (43). Since $C$. tamariscifolia was reported only once, in only one location, in the absence of the sample this record should be treated as an misidentification.

\section{CONCLUSION}

Based on our 12-year-long field investigations and published data, the species C. compressa subsp. pustulata, C. crinita, C. crinitophylla and C. sqarrosa resulted to be 
rare and endangered along the Montenegro coast as they were reported only with 33 records. As a confirmation of this statement are findings of Macic et al. (17) were along the Montenegro coast, for the same investigated period, were reported 6 most common Cystoseira species with 264 records. Namely they are $C$. amentacea var. spicata, $C$. barbata, C. compressa, C. corniculata ssp. laxior, C. foeniculacea and C. spinosa. On the base of our survey and all previous findings presence of 9 Cystoseira species is confirmed.

Published data for $C$. sauvageauana is likely mistaken due to incomplete and poorly conserved algal material, while the $C$. tamariscifolia reference should be checked if a collected sample has been preserved. In the absence of the sample of $C$. tamariscifolia this record also should be treated as an misidentification.

Acknowledgements: The authors acknowledge with thanks the valuable suggestions of anonymous reviewers and of the editor.

\section{REFERENCES}

1. AMICO V 1995 Marine brown algae of family Cystoseiraceae: Chemistry and chemotaxonomy. Phytochemistry, Vol. 39. no.6:12571279 http://dx.doi.org/10.1016/0031-9422(95)00199-H

2. COLL M, PIRODDI C, STEENBEEK J, KASCHNER K, BEN RAIS LASRAM F, AGUZZI J, BALLESTEROS E, NIKE BIANCHI C, CORBERA J, DAILIANIS T, DANOVARO R, ESTRADA M, FROGLIA C, GALIL B, GASOL J, GERTWAGEN R, FRANCOIS GUILHAUMON J, KESNER-REYES K, KITSOS MS, KOUKOURAS A, LAMPADARIOU N, LAXAMANA E, DE LA CUADRA L, LOTZE H, MARTIN D, MOUILLOT D, ORO D, RAICEVICH S, RIUS-BARILE J, SAIZ-SALINAS JI, SAN VICENTE C, SOMOT S, TEMPLADO J, TURON X, VAFIDIS D, VILLANUEVA R, VOULTSIADOU E 2010 The Biodiversity of the Mediterranean Sea: Estimates, Patterns, and Threats. http://www.plosone.org/article/info\%3Adoi\%2F10.1371\%2 Fjournal.pone.0011842 (Accessed 27 February 2012)

3. OLIVERASPLA M, GOMEZ GARRETA A 1989 Corologia del genero Cystoseira C. Agardh (Pheophyceae, Fucales). Anales Jardin Botanico de Madrid, 46(1), 89-97

4. DRUEHL L 2000 Pacific seaweeds. A guide to common seaweeds of the West Coast. Harbour Publishing, BC Canada, pp.190

5. GUIRY MD, GUIRY GM 2013 AlgaeBase. World-wide electronic publication, National University of Ireland, Galway. http://www. algaebase.org (Accessed 13 February 2013).

6. ERCEGOVIĆ A 1952 Jadranske cistozire, njihova morfologija, ekologija i razvitak. Fauna et Flora Adriatica Vol II. Split, pp 212

7. RIBERA MA, GOMEZ GARRETA A, GALLARDO T, CORMACI M, FURNARI G, GIACCONE G 1992 Check-list of Mediterranean seaweeds, I Fucophyceae (Warming, 1884). Bot. Mar. 35: 109-130 http://dx.doi.org/10.1515/botm.1992.35.2.109

8. CORMACI M, FURNARI G, CATRA M, ALONGI G, GIACCONE G 2012 Flora marina bentonica del Mediterraneo: Phaeophyceae. Bollettino dell'Accademia Gioenia 45: 1-508

9. FURNARI G, GIACCONE G, CORMACI M, ALONGI G, SERIO D 2003 Biodiversita marina delle coste Italiane: Catalogo del macrophytobenthos. S.I.B.M. Genova, Erredi Grafiche Editoriali S.n.c. pp: 482
10. ANTOLIĆ B, ŠPAN A, ŽULJEVIĆ A, NIKOLIĆ V, GRUBELIĆ I, DESPALATOVIĆ M, CVITKOVIĆ I 2010 A checklist of the benthic marine macroalgae from the eastern Adriatic coast: II. Heterokontophyta: Phaeophyceae. Acta Adriat., 51(1.): 9 - 33

11. THIBAUT T, BLANFUNE A, BOUDOURESQUE CF, VERLAQUE M. 2015 Decline and local extinction of Fucales in the French Riviera: the harbinger of future extinctions? Medit. Mar. Sci., 16/1, pp: 206-224

12. UNEP, RAC-SPA, 2009 Proposals for amendment of Annexes II and III of the SPA/BD Protocol. Ninth Meeting of Focal Points for SPAs Floriana, Malta, 3-6 June 2009

13. THIBAUT T, PINEDO S, TORRAS X BALLESTEROS E 2005 Long-term decline of the populations of Fucales (Cystoseira spp. and Sargassum spp.) in the Alberes coast (France, North-western mediterranean). Mar. Pollut. Bull. 50: 1472-1489

14. BENEDETTI-CECCHI L, PANNACCIULLI F, BULLERI F, MOSCHELLA PS, AIROLDI L, RELINI G, CINELLI F 2001 Predicting the consequences of antropogenic disturbance: largescale effect of loss of canopy algae on rocky shores. Mar. Ecol. Prog. Ser. Vol. 214: 137-150 http://dx.doi.org/10.3354/meps214137

15. MACIC V 2007 Rasprostranjenost alge Cystoseira barbata u unutrašnjem dijelu Bokokotorskog zaliva. Vode 2007. Tara, 26-29. jun 2007, pp: 263-266

16. THIBAUT T, MANNONI PA, MANGIALAJO L, BOTTIN L MACIC V 2009 Regression of the Cystoseira populations in the Mediterranean Sea-the case of the French coast. ASLO Aquatic Sciences Meeting 2009, 25-30 January, Nice. Abstract book, pp. 263

17. MACIC V, THIBAUT T, ANTOLIC B, SVIRCEV Z 2010 Distibution of the most common Cystoseira species on the coast of Montenegro (South-East Adriatic Sea). Fresen. Environ. Bull. Vol.19, No.6: 1191-1198

18. PROSTORNI PLAN PODRUČJA POSEBNE NAMJENE ZA MORSKO DOBRO (PPPPNzMD) 2007 Ministarstvo za ekonomski razvoj Republike Crne Gore, Javno preduzeće za upravljanje morskim dobrom Crne Gore. Obrađivači MonteCEP i Republički zavod za urbanizam i projektovanje, Podgorica, pp 79

19. HOLMGREN PK, HOLMGREN NH 2003 Additions to index Herboriorum (Herbaria), Edition 8 - Fourteenth Series. Taxon 52, May 2003, pp: 385-389

20. QGIS Software Date 20. March 2015 http://www.qgis.org/en

21. MAČIĆ V 2011 Destrukcija priobalnih staništa - rastući problem u Crnoj Gori. Zaštita prirode u XXI vijeku, Zbornik referata, rezimea referata i poster prezentacija (Knjiga 2), 20-23 septembar 2011., pp. $925-926$

22. GIACCONE G, BRUNI A 1973 Le Cistoseire e la vegetazione sommersa del Mediterraneo. Atti Ist. Veneto Sci., Lett. ed Arti Venezia, 131: 59-103

23. SAUVAGEAU C 1912 A propos des Cystoseira de Banyuls et de Guethary. Bulletin de la station biologique D'Arcachon, Quatorzieme annee (1911-1912), Bordeaux, pp: 133-540

24. ŠPAN A, ANTOLIĆ B 1987 Studija o srednjem Jadranu Jugopetrol - Kotor (Uvala Trašte) I and III Knjiga pp: 703

25. GOMEZ GARRETA A 2001 Flora Phycologica Iberica, Vol. 1. Fucales. Universidad de Murcia, Servicio de Publicaciones, 2000. pp. 192

26. PIZZUTO F 1997 Fenologia morgologica e riproduttiva di Cystoseira crinita Duby (Fucales, Fucophyceae) di isola delle Correnti (Siracusa, Italia). Boll. Acc. Gioenia Sci. Nat. Vol. 30, n. 353, pp: 129-136

27. PIZZUTO F 1999 On the structure, typology and periodism of a Cystoseira brachycarpa J. Agardh emend.Giaccone community and of a Cystoseira crinita Duby community from the eastern coast of 
Sicily (Mediterranean Sea). Plant biosystems, 133 (1): 15-35 http:// dx.doi.org/10.1080/11263509909381529

28. VERGES A, ALCOVERRO T, BALLESTEROS E 2009 Role of fish herbivory in structuring the vertical distribution of canopy algae Cystoseira spp. in the Mediterranean Sea. Marine Ecology Progress Series, 375, 1-11 http://dx.doi.org/10.3354/meps07778

29. ŠPAN A, ANTOLIĆ B 1992 The inventory of benthic flora of the Bay Boka Kotorska (southern Adriatc). Acta Adriat. 33 (1/2): $75-84$

30. STJEPČEVIĆ B, IVANOVIĆ-KALEZIĆ A 1999 Rasportd, karakteristike i funkcionalnost podmorskih kanalizacionih ispusta duž crnogorskog primorja. Zaštita voda 1999, pp: 337-342

31. MAČIĆ V, KAŠĆELAN S 2006 Caulerpa racemosa on the Montenegrian coast. $38^{\text {th }}$ Rapp. Comm. int. Mer Medit., Istanbul, 9-13 April 2007. 38, pp. 533

32. SOLAZZI A 1971 Reperti algologici delle Bocche di Cattaro. Thalasia Salientiana 5. 3-18

33. HAMEL G 1931-1939 Pheophycees de France. Paris, pp:384-431

34. GIACCONE G, COLONNA P, GRAZIANO C, MANNINO AM, TORANTORE E, CORMACI M, FURNARI G, SCAMMACCA B 1985 Revisione della flora marina di Sicilia e isole minori. Bolletino dell'Accademia Gioenia di scienze naturali. Catania 18: 537-781

35. MOTTA G 1989 Fenologia morfologica e riproduttiva di Cystose ra sauvageauana Hamel (Phaeophycophyta, Fucales). Boll. Acc. Gioenia Sci. Nat. Vol.22, N.335: 317-334

36. CORMACI M, FURNARI G, GIACCONE G, SCAMMACCA B, SERIO D 1992 Observations taxonomiques et biogéographiques sur quelques espèces du genre Cystoseira C. Agardh. Bulletin de l'Institut Océanographique Monaco, n spécial: 21-36
37. KRIVOKAPIĆ S, PESTORIĆ B, BOSAK S, KUŠPILIĆA G, RISEL CW 2011 Trophic state of Boka Kotorska Bay (south-eastern Adriatic Sea). Fresen. Environ. Bull. Vol. 20., No. 8:1960-1969

38. AMICO V, CUNSOLO F, NERI P, PIATTELLI M, RUBERTO G 1988 Antimicrobial tetraprenyltoluquinol derivates from Cystoseira spinosa var. squarrosa. Phytochemistry, Vol. 27, No.5: 1327-1331 http://dx.doi.org/10.1016/0031-9422(88)80187-0

39. ALONGI G, CATRA M, CORMACI M, FURNARI G 2002 Observations on Cystoseira squarrosa De Notaris (Fucophyceae, Fucales) a rare and little known Mediterranean species and its typification. Bot. Mar. 45: 530-535 http://dx.doi.org/10.1515/ BOT.2002.056

40. ŠPAN A, ANTOLIĆ B 1983 Prilog poznavanju fitobentosa Crnogorskog primorja (Južni Jadran). Studija Marina 13-14, 87-110

41. THIBAUT T, BALLESTEROS E 2005 First report of Cystoseira squarrosa De Notaris (Fucophyceae, Fucales) from Spanish coastal waters. Cryptogamie, Algol., 26(2. 203-207

42. MAČIĆ V 2008 Novo nalazište invazivne alge Womersleyella setacea (Hollenberg) R.E. Norris u crnogorskom podmorju. Vode 2008, Mataruška banja 3-6. jun 2008. pp: 293-296

43. LOVRIĆ A Z̆, RAC M 2006 Algal and halophytic vegetation in Platamuni sea-cliffs and related Montenegro coast, southeastern Adriatic. Period. Biol. Vol. 108., No.2., 189-202

44. SOUHAILI Z, LAGZOULI M, FAID M, FELLAT-ZERROUCK K 2004 Inhibition of growth and mycotoxins formation in moulds by marine algae Cystoseira tamariscifolia. Afr. J. Biotechnol. Vol. 3(1), pp: 71-75 http://dx.doi.org/10.5897/AJB2004.000-2013

45. GIACCONE G 1972 Struttura, ecologia, e corologia dei popolamenti a Laminarie dello Streto di Messina e del mare di Alboran. Mem. Biol. Mar. Oceanohr.Univ. Messina, 2: 37-59 